Hans-Christian Brauweiler, Doctor rerum politicarum, Full Professor, Professor honoris causa, Doctor honoris causa, Chair of Business Administration, Management Accounting and Internal Audit, University of Applied Sciences Zwickau (Zwickau, Germany);

Viktoriia Shkola, Candidate of Economic Sciences, Associate Professor, Associate Professor of Economic Theory Department, Sumy State University (Sumy, Ukraine);

Olena Markova,

Candidate of Legal Sciences, Associate Professor of Legal Disciplines Department, Sumy Branch of the Kharkov University of Internal Affairs (Sumy, Ukraine)

\title{
ECONOMIC AND LEGAL MECHANISMS OF WASTE MANAGEMENT IN UKRAINE
}

The article deals with current problems of waste management in Ukraine. Essence of economic and legal mechanisms of waste management is defined within system approach. Up-to-dated methods of waste management are examined by authors. The analysis of the legal norms provides the improvement of system main directions.

Keywords: waste, waste management, waste management sector, economic and legal mechanisms, secondary resources.

DOI: 10.21272/mmi.2017.2-33

Problem statement. The problem of waste is not new for Ukraine, but it has not been solved yet. Accumulation of various wastes in the environment is one of the factors to destabilize the ecological situation and ecological security in the country, guaranteed by Article 50 of the Constitution of Ukraine [1] i.e. everybody's right for safe life and environmental health.

Ukraine is obliged for natural environment protection and maintaining an ecological balance [1]. Its function is performed by the central and local authorities. According to current legislation in Ukraine, system of subjects in the environmental protection system includes legislative and executive authorities, self-governing authorities, and specially authorized (environment-oriented) jurisdiction [2]. Economic and legal control of relations in waste management sector, waste utilization or recycling have strategic values, taking into account the fact that ecological security is inalienable part of national security according to the Law of Ukraine On the Fundamentals of National Security of Ukraine on June, 192003 № 964-IV [3].

That is precisely why nowadays basic direction of state policy in Ukraine is to form effective economic and legal mechanisms for relationships control in waste management sector oriented to create national resource-effective system for waste management with both material and energy flows, based on zero waste and circular economy principles.

Analysis of the recent research and publications. The issues of waste management are investigated in papers [4-8]. Works of both Ukrainian scientists (such as V.I. Andreytsev [9], G.I. Balyuk [10], L.O. Bondar [11], A.G. Getman [12], L.V. Derkachova [13], V.I. Savulyak and O.V. Berezyuk [14], and Y.S. Shemshuchenko [15] ect.) and foreign scientists (in particular, M. Coffey [16], L.M. Johannessen [17] ect.) represent the problems on legal regulation of relations in the waste management sector. At the same time, although there are significant achievements, the problem to

\footnotetext{
${ }^{1}$ The paper was written according to budget money from the Ministry of Education and Science in Ukraine, given to develop research topic № 53.15.01-01.15/17.GF "Methodology of forming mechanism of national economy innovative development based on alternative energy".
} 
provide effectiveness of current waste management system considering circular economy transfer requirements, growing of the national economy competitiveness at the world market, and providing sustainable economic growth, have to be solved. It stipulates the necessity to form new economic and legal mechanisms of waste management, based on zero waste principles and sustainable development.

The object of the article is to improve the economic and legal mechanisms of waste management in Ukraine. The following tasks are set for its solving: to analyze the problems in the waste management sector; to define essence of the economic and legal mechanisms in the waste management sector and its main constituents, to investigate methods and tools to control the waste management system.

Results. After Ukraine has joined the European Council and has implemented the program on adaptation of Ukrainian Law to European Union's regulations and standards, Ukraine has been obligated to solve problems in waste management sector. At the same time, analyzing current problems in waste management sector, those ones should be emphasized, without solving of which it is impossible to provide effectiveness and efficiency of national waste management system. Those are:

1) legal:

- weak mechanism for relationship regulation connected with services providing in waste management sector (in particular, collection, storage, transport, recycling, and utilization). There is no mechanism to provide obligations fulfillment in the sector;

- imperfect system of responsibility consumer, producers, and competent authorities;

- imperfect tender procedure on services connected with waste;

- absence of effective programs aimed on environmental education;

- lack of public-private partnership in the sector;

- absence of the proper state control for compliance with legislation in the waste management sector;

- absence of a law governing the Secondary Material Resources;

- absence of real state control over the waste formation and conduct with them, as a result of which more than $60 \%$ is used in the shadow economy and only $10 \%$ is controlled by government [18];

2) economic:

- absence of the economic motivation;

- unbalanced taxing system in the waste management sector;

- absence of the economically structured system of fines in the waste management sector;

- absence of the active motivational controlling mechanism in the waste management sector, in particular, economic incentives for producers to put greener products on the market and support recovery and recycling schemes (e.g. for packaging, batteries, electric and electronic equipment, vehicles).

- absence of active economic instruments to discourage landfilling;

- absence of the formed domestic markets of the recycled raw materials (state and private markets);

- absence of the economically structured, simplified and harmonized methods with international legislation norms for recycling norms determination;

- unturned accurate record of the economic entities, which creates oil wastes as a result of their productive activity;

- absence of effective oil waste collection system, which really keeps the investments inflow into the productive capacities for recycling in Ukraine;

- discrepancy of the productive capacities with ecologically safe disposal, utilization, regeneration of waste;

- licensing of the "pseudo-activity" on oil waste recycling without proper control of its results;

- difficulties to involve foreign investments, caused by great risk of innovative processes 
introduction in Ukraine and absence of the state executive authorities' detailed activity concerning waste management system [18];

3) social:

- underdeveloped system of environmental education, producers' and consumers' environmental consciousness;

- poor standards of citizens' ecological culture and environmental consciousness;

- reluctance in each household to put forward work and effort to sort garbage;

4) technical:

- unsolved logistics;

- unsolved separation questions and treatment processes.

Besides nowadays current regulatory and legal framework in waste management is not conformed to EU Directives concerning wastes, including those ones, which Ukraine is obligated to transport according to Association Agreement. Main EU principles on waste management have not been fulfilled in Ukraine yet [19]. Basic vocabulary, used in the proper acts of Ukraine, is not conformed to definitions in the EU waste regulatory documents. Problems in the legal regulation, particularly at the stage of law enforcement and realization in the waste sector, in delay of proper EU standards introduction, lead to legal uncertainty, which discredits foreign investors.

The suggested economic and legal controlling mechanism of the waste management system has to be oriented to solve problems mentioned above.

Generalizing investigations [20-24], economic and legal controlling mechanism of the waste management sector is proposed to be defined as a system of relationship between stakeholders, based on principles, elements, economic and legal means of the managerial impact, used to regulate ecological and economic legal relations for state's ecological policy tasks and objectives achievement. It should be noted that the mechanism is closely related to and depended on society economic, political, legal and cultural system, on specifics of state mechanism framing and functioning, as well as on ecological and legal culture of legal subjects [9, p. 14].

The general structure of the mechanism is shown in figure 1.

Target subsystem of the shown mechanism includes goals and tasks based on property management levels. Taking into account European integration processes, the suggested mechanism has to be oriented on achievement of objectives, set by world community (in particular regarding the growth of household waste recycling up to $65 \%$, packaging waste - up to $75 \%$, reduction of household waste dumping to $10 \%$ and prohibition on separately collected waste dumping by 2030 [25]).

Controlling subsystem comprises system of state government authorities and local government, which directly and indirectly regulates relations dealing with waste, according to the Law of Ukraine On the waste [26]. Cabinets of Ministers of Ukraine competence provides organizational and economic bases in the waste management system, motivates separate collection and utilization of wastes. The powers of local state administrations and local governments include organization of waste disposal and separate collection, creation of the necessary conditions to involve people to collect and to stock some wastes as secondary raw materials etc. It should be noted, today most references to the liability to implement the system of separate collection of waste are in the program documents.

Analyzing the competence constituent of the state government authorities, one should point out the necessity to define clearly each subject's competence in this system, based on differentiation between management and controlling function in the ecological sector. Taking this into consideration, state ecological inspections with double or even triple liability and accountability are subjected to reformation. It greatly prevents from fulfillment the effective management function in regions and determines their formal state. In this case it is necessary to distinguish "inspection" tasks and functions of these bodies from "managerial" ones. It will assist their effective fulfillment [27, p. 135]. 
Х.-К. Браувэйлер, В.Ю. Школа, Е.О. Маркова. Економіко-правовий механізм управління у сфері поводження 3 відходами в Україні

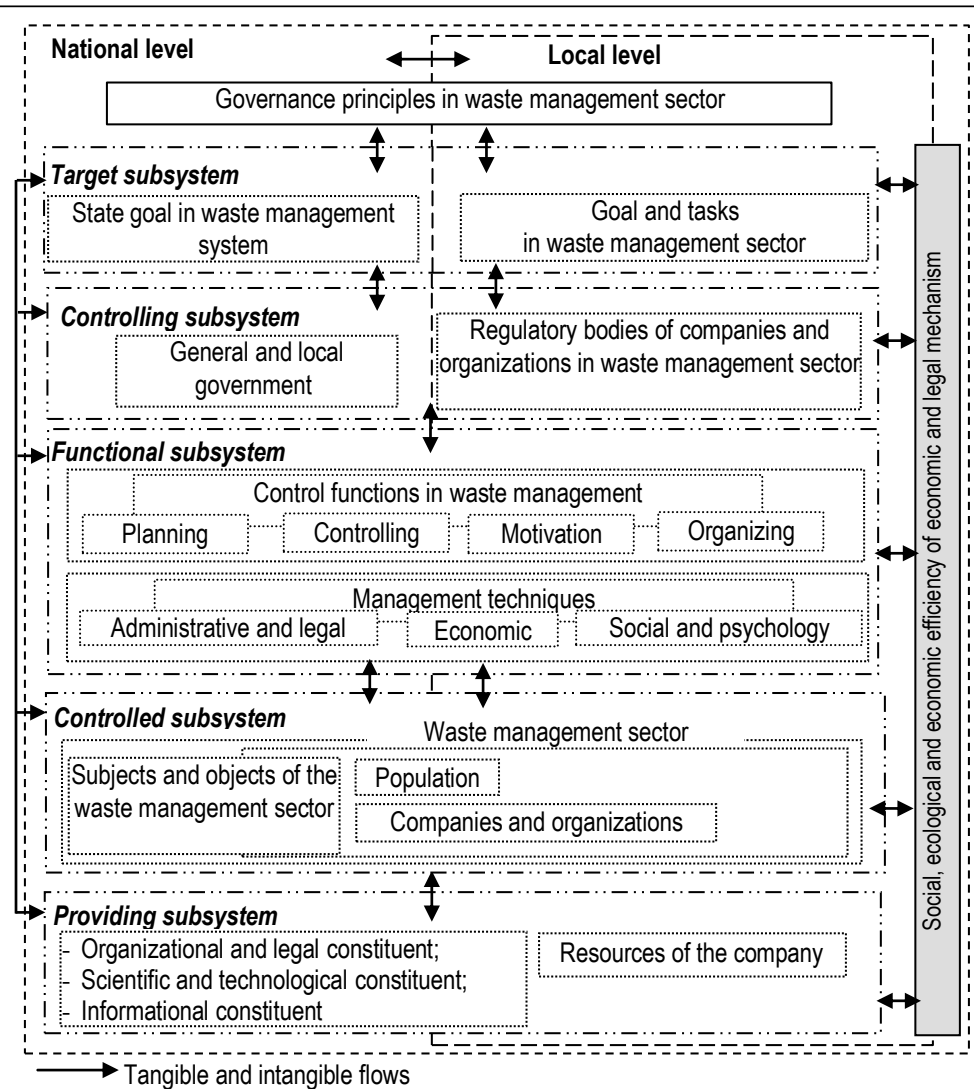

Figure 1 - The economic and legal mechanisms of waste management (developed by authors)

The system of state control and observation requires to be improved in the hazardous waste management sector through controlling bodies' activity functional bases specification and avoiding of their mutual duplication; gaps in the separate spheres of the functional activity and introduction of the persons' responsibility mechanism of these bodies.

Controlled subsystem is represented by subjects and objects, involved directly or indirectly in the waste management system controlling.

Providing subsystem of the economic and legal controlling mechanism in waste management sector contains providing infrastructure elements, presented by institutions and organizations related indirectly to waste management sector, as well as economic entities resoures. The providing infrastructure task is to inform producers and consumers with aim of their cultural education, to form and raise environmental awareness degree and environmental impairment liability of citizens and economic entities, to form staff potential for state administration sector, production sector, service sector and trade.

Functional subsystem of the economic and legal controlling mechanism in waste management sector comprises several functions, which are performed by the state authorities and local governments within the framework, established by legislative acts at the state and local levels [13, p. 23], and also administrative and legal, economic, social and psychological methods and management tools. Local governments perform functions concerning development and approval of sanitation schemes and rules 
of cities' and towns' territories accomplishment, local programs of waste management; organization of collecting, transporting, utilization and disposal of wastes; providing localities with allowance to accumulate and to dispose wastes; control for rational use and protective conduct with wastes at the own territory; creation of the necessary conditions to involve people in accumulation and stock of some wastes as the recycled materials; providing people with information concerning local programs realization in the waste management sector, assisting of government's explanation about wastes.

As it is mentioned in [28], economic methods in the waste management sphere are tools of the market or indirect impact on producers' of waste managers' economic interests in order to focus their activity on the ecologically favorable direction. The economic methods include [28-31] ecological tax and costs for waste location, financing of the ecological projects and programs, ecological taxes and fees for environmental pollution, emissions, natural resources use and fees for their extra usage, ecological insurance and ecological standardization, subsidies and discounts, selling of rights for pollution.

Social and psychology methods are based on moral responsibility and assist forming of ecological intellect, ideology and basic principles of the effective waste management. These methods are based on persuasion, moral impact on human's psychology. It leads to stimulate development of the ecological social values concerning public individuals' position activation, with purpose to keep environment position for future generations [28]. This group of methods includes ecological education, ecological advertisement and PR, state demonstrative projects, methods of the moral encouragement and blame, producers' extended responsibility and others.

Observing the classification of administrative and legal methods [32, p. 98], general and special methods have to be distinguished. General methods include legal consciousness, legal culture, legality, law and order; special methods include legal norms, regulatory provisions, legal relations, acts of law and obligations implementing, acts of laws use, acts of the official interpretation, contracts and other contractual forms, subjective rights, legal obligations, permissions, prohibitions, law-making and law enforcement actions etc.

This group of methods pays great attention to contracts, which play significant role in legal relations regulation in the waste management sphere, because it is an effective legal mean for rights, obligations and rules setting between sides, which are entering it. Under conditions of the market relations, contracts as a self-regulation tool play significant role. Freedom and equality of sides provide free will to enter into the contractual relations without any administrative restrictions. Contract is an effective mean in the process of legal permissions and prohibitions realization [33, p. 58]. Permissions do not have realization mechanism, as a rule, a subject controls them. In this case he has to coordinate his actions on legal permission realization with other subjects' will, whose active or passive behavior is necessary to realize permissions. According to this, legal relations have to be formed between these subjects. It means that contract is the main tool for permissions realization. Since the permissions list, fixed in the regulatory acts, is not finished, realization of permissions is not legally regulated. The main function of the contract is to create a right, in other words to create legal general or individual norm.

In this case norms of the contract are the means which provide implementation of the permission by the concrete person. In the contracting process norms are created. They are individual, i.e. those ones, which concern concrete defined individuals and are designed to them, as a result of which "micronorms" or "macronorms" are created [34, p. 28]. As it is mentioned in [16, p.124], in the waste management sphere in the European Union countries such contract forms are used: contracting, franchising, private subscription or open competition (tender), and concession.

The system of legal norms, fixed in the proper legislative acts, is oriented to provide environmental protection on a whole, and waste management sphere particularly, including the Law of Ukraine On the Waste [26], the Law of Ukraine On the Environmental Protection [2], the Law of Ukraine On Sanitary and epidemiological public welfare provision [35]; the Law of Ukraine On main fundamentals (strategy) of the 
state ecological policy of Ukraine till 2020 [36] etc. During the last five years about one thousand various programs and about 200 conceptions for development of Ukraine were accepted. Practically each of them provides development of proper programs at the regional level. As a result of such programs with limited financing, many problems have not been performed yet [37].

Analyzing the system of legal norms, it is necessary to point out that some main positions require to be improved, particularly:

- extending of the conceptual system and specification of the waste value as recycled materials and peculiarities of secondary resources conduct;

- determination of wastes categories, which have to be used as recycled raw materials from the viewpoint of economic and ecological reasonability with needs and resource peculiarities in every region;

- introduction of norms, which provide to use separate waste collection;

- creation of the reporting system for creation, processing, utilization and location of wastes;

-introduction of norms, which provide goods producers' responsibility, which lost their consumer properties, for their following utilization; obligations of producers and sellers of containers, suitable for several times of use (production in such containers), provide receive and payment for its deposit price. The producer's extended responsibility is a strategic approach, according to which producers take great financial and/or physical responsibility to recycle or to dispose consumption wastes. Such responsibility can provide stimulus for prevention from waste storing at the pollution source, can assist ecological design of production and support in goals achievement with wastes recycling and material flows control at the state level;

- given the imperfection of the current legal responsibility system it is necessary to make some changes in Code of administrative offenses [38] in the part concerning fees for offenses in the waste management system for consumers when contracts for service on waste exportation are not concluded with service provider, and also producers and competent bodies, which perform controlling and supervisory function in the waste sphere, i.e. creation of the reverse system of all subjects' responsibility;

- deprivation of license caused by economic entity's violation of license terms concerning hazardous waste management, and procedure of import to Ukraine and transit of waste as recycled materials on its territory;

- given the fact that there is a lack of administrative and criminal responsibility norms for breaking of rules for industrial waste collecting, accumulating, transporting and using, it is necessary to fix an article in Criminal Code of Ukraine [39] concerning determination of responsibility for violations in the hazardous waste sphere.

Thus, realization of the suggested actions will lead to increase efficiency of the waste management system.

Conclusions and perspectives for further studies. Integral results of the research consist in the theoretical and practical bases for relations legal control in the waste management sector and improvement of the economic and legal controlling mechanism in this sector. The economic and legal mechanisms in the waste management system, proposed by authors, will lead to investigate theoretical and methodic approach to the breakthrough management in the waste management sector as a global system in further studies. It will assist regulating of relations in the waste management sector, based on preventive, simulative and compulsory actions in relation to legal and private persons, competent authorities for use, recycle and utilization of waste and implementation of the legal responsibility for violations in this sector.

Thus, issues, formed by authors, lead to develop theoretical and methodic approach to the breakthrough management in the waste management sector as a global economic system. Besides, relationship mechanism on waste management between countries is developed, which will facilitate formation and innovative development of waste management national systems, based on the net cooperation and state-private partnership. 
1. Конституція України // Відомості Верховної Ради України. -1996. - № 30.

2. Закон України «Про основи національної безпеки України» від 19 червня 2003 року № 964-IV // Відомості Верховної Ради України від 26.09.2003 - 2003 р. - № 39.

3. Про охорону навколишнього природного середовища : закон України від 25 черв. 1991 р. № 1264-XII // Відомості Верховної Ради України. - 1991. - № 41.

4. Brauweiler H.-C. Umweltmärkte Mittel- und Osteuropa - Potentiale für kleine und mittelständische Unternehmen mit innovativen Angeboten, / Hans-Christian Brauweiler, Pavla Vojtasová, Jiri Hrebicek // Deutsch-tschechischer Workshop, Sammelband zur 7. Internationalen Fachmesse Envibrno, Brno (Brünn, Tschechische Republik). - 1998.

5. Gibbs A. Development of a Modelling Tool on Waste Generation and Management. Headline Project Report. Final Report for the European Commission DG Environment under Framework Contract № ENV.C.2/FRA/2011/0020 [Electronic resource] / A. Gibbs, T. Elliott, T. Vergunst, A. Ballinger, D. Hogg, et al. - Bristol: Eunomia Research \& Consulting Ltd. - Access mode: http://www.cri.dk/sites/cri.dk/files/cases/eu_waste_model_-_headline_report_v1.0.pdf.

6. Hogg, D. Support to the waste targets review. Analysis of new policy options [Electronic resource] / D. Hogg, T. Vergunst, T. Elliott, L. Elliott, M. - Corbin. Bristol: Eunomia Research \& Consulting Ltd. - Access mode: http://ec.europa.eu/environment/waste/pdf/Analysis\%20of\%20New\%20Policy\%200ptions\%20Eunomia\%20report\%202015.pdf

7. Klampfl-Pernold H. Quantensprünge in der Abfallwirtschaft - Entwicklung eines innovationsorientierten Phasenmodells der europäischen Abfallwirtschaft / H. Klampfl-Pernold, U. Gelbmann. - Aachen: Shaker Verlag, 2006.

8. Kramer M. Internationales Umweltrecht: Ein Vergleich zwischen Deutschland, Polen und Tschechien / Matthias Kramer, Hans-Christian Brauweiler. - Wiesbaden : Deutscher Universitäts-Verlag : Gabler, 1999.

9. Андрейцев В.И. Гарантии эффективности экологической экспертизы: социально-правовые проблемы / В.И. Андрейцев - К.: Знание, 1992. - 20 с.

10. Балюк Г.І. Проблеми удосконалення юридичної відповідальності за екологічні правопорушення в контексті сталого розвитку України / Г.І. Балюк // Вісник Київського нац.університету ім. Т. Шевченка. - 2007. - Випуск 74. - с. 7-10.

11. Бондар Л.О. Екологічне право України : навч. посібник / Л. О. Бондар, В. В. Курзова. - 2-ге вид., доп. та перероб. Х. : Бурун Книга, 2008. - 368 с.

12. Гетьман А.П. Кодифікація законодавства про довкілля: теорія та методологія [ Текст] / А.П. Гетьман // Екологічний вісник. - 2009. - №3. - С. 31-32.

13. Деркачова Л.В. Законодаче закріпленя рециклінгу як необхідної новації у сфері поводження з відходами : Автореферат на здобуття наук. ступеня К.Ю.н./ Л.В. Деркачова. - К., 2011. - 30 с.

14. Савуляк В.І. Технічне забезпечення збирання, перевезення та підготовки до переробки твердих побутових відходів: Монографія. / В.І. Савуляк, О.В. Березюк - Вінниця: УНІВЕРСУМ-Вінниця, 2006. - 218 с.

15. Шемшученко Ю.С. Национальные интересы и Экологическое право / Ю.С. Шемшученко // Журнал российского права. - 2005. - № 12. - С. 92-96.

16. Manus C. Collection of Municipal Solid Waste in Developing Countries / C. Manus, A. Coad. - Kenya, 2010. - P. 122-126.

17. Johannessen L.M. Guidance Note on Recuperation of Landfill Gas from Municipal Solid Waste Landfills / L.M. Johannessen // Urban Waste Management. - V. 4. - 1999. - P.34.

18. Школа В.Ю. Перспективы инновационного развития национальной экономики на основе вторичной переработки отходов / Школа В.Ю., Прокопенко О.В., Домашенко М.Д. // Устойчивое развитие предприятия, региона, общества: инновационные подходы к обеспечению: монография / под общ. ред. д-ра экон. наук, профессора О. В. Прокопенко. Польша : «Drukarnia i Studio Graficzne Omnidium», 2014. - 474 c. - C. 217-228.

19. Handbook on the Implementation of EC Environmental Legislation [Electronic source]. - Access mode: http://ec.europa.eu/environment/enlarg/handbook/i ntro.pdf

20. Детермінанти соціально-економічного розвитку підприємств: монографія, вип. 2 / за наук. ред. д-ра екон. наук. проф. Є. В. Мішеніна. - Харків: ТОВ «Діса Плюс», 2013. - 444 с.

21. Ілляшенко С.М. Формування ринку екологічних інновацій: економічні основи управління: монографія / за ред. д.е.н., проф. С.М. Ілляшенка. - Суми, ВТД «Університетська книга», 2002. - 250 с.

22. Парвина Т.Г. Суть організаційно-економічного механізму управління інноваційною діяльністю [Електронний ресурс] / Т.Г. Парвина. - Донецьк: ДонНТУ, 2008.2 - Режим доступу: http://masters.donntu.edu.ua/2008/fem/parvina/library/st1.htm

23. Фролова А.В. Формування організаційно-економічного механізму управління забезпеченням екологічної безпеки держави [Електронний ресурс] / А.В. Фролова // Проблеми системного підходу в економіці. - 2011. - №4. - Режим доступу: http://archive.nbuv.gov.ua/e-journals/pspe/2011_4/Frolova_411.htm.

24. Шкільнюк О.М. Організаційно-економічний механізм регулювання інноваційної діяльності: автореф. дис... канд. екон. наук, спец.: 08.00.03 - економіка та управління національним господарством / О.М. Шкільнюк. - К. : Науководослідний економічний ін-т, 2008. - 18 с. 25. Review of Waste Policy and Legislation [Electronic source]. - Access mode:
http://ec.europa.eu/environment/waste/target_review.htm

26. Закон України «Про відходи» від 5 березня 1998 р. № 187/98-ВР [Електроний ресурс] - Режим доступу: www.rada.gov.ua. 
27. Казанчук І. Д. Удосконалення адміністративно-правового регулювання діяльності органів виконавчої влади щодо охорони навколишнього природного середовища в умовах інтеграції України у Європейський союз [Електроний ресурс] / І.Д. Казанчук // Вісник Харківського національного університету внутрішніх справ. - 2010. - №3. - С.131-138. - Режим доступу: http://nbuv.gov.ua/UJRN/VKhnuvs_2010_3_19.

28. Зарічанська Є.В. Організаційно-економічний механізм поводження з промисловими відходами : дис. ... канд. екон. наук : 08.00.04 - економіка та управління підприємствами (за видами економічної дыяльності) / Є.В. Зарічанська; Держ. вищ. навч. заклад «Донецький національний технічний університет». - Донецьк., 2013. - 235 с.

29. Малєй О.В. Шляхи удосконалення економічного механізму управління сферою поводження з твердими побутовими відходами на регіональному рівні [Електронний ресурс] / О.В. Малєй // Комунальне господарство міст. - 2013. - № 111. - C. 41-47. - Режим доступу: http://eprints.kname.edu.ua/35341/1/41-47\%20\%D0\%9C\%D0\%B0\%D0\%BB\%D1 \% 94\% D0\%B9\%20\%D0\%9E\%D0\%92.pdf.

30. Ячменева В.М. Экономический механизм обеспечения экологической безопасности региона как объект управления / В.М. Ячменева, Н. В. Зайцев //Культура народов Причерноморья. - 2005. - №74. - Т.1. - С. 100-104.

31. Basiye K. K. Extended producer responsibility for the management of waste from mobile phone / Karen Khayanje Basiye // Thesis for the fulfillment of the Master of Science in Environmental Sciences: June 2008. - Lund, Sweden, 2008. - 96 p.

32. Скакун О.Ф. Теорія держави і права : підручник. / О.Ф. Скакун - Х., 2011. - С. 98

33. Некрасова М.Е. Договор как теоретико-правовая категория : дис. ... канд. юрид. наук. / М.Е. Некрасова - М., 2004. C. $56-87$.

34. Тихомиров Ю.А. Договор как регулятор общественных отношений / Ю.А. Тихомиров // Правоведение. - 1990. № 5. - C. $27-35$.

35. Закон України «Про забезпечення санітарного й епідемічного благополуччя населення» [Електронний ресурс]. Режим доступу: http://zakon3.rada.gov.ua/laws/show/4004-12.

36. Закон України «Про Основні засади (стратегію) державної екологічної політики України на період до 2020 року» [Електронний ресурс] - Режим доступу: http://zakon3.rada.gov.ua/laws/show/2818-17.

37. Національна стратегія поводження з твердими побутовими відходами в Україні: [Електроний ресурс]. - Режим доступу: http://eco.kiev.ua/novyny/nac_strategija_povodjennja_z_vidkhodamy/?gclid=CjOKEQjww7zHBRCToPSj_c_ WiZIBEiQAj8il5Ab4Rx-XCel8OkxnEgOjpYoci-nuy87FhfNfsxpfRx8aApD58P8HAQ.

38. Кодекс про адміністративні правопорушення [Електронний ресурс]. - Режим доступу: http://zakon3.rada.gov.ua/laws/show/80731-10.

39. Кримінальний кодекс України [Електронний ресурс]. - Режим доступу: http://zakon3.rada.gov.ua/laws/show/2341-14.

1. Konsty 'tuciya Ukrayiny' [The Constitution of Ukraine] (1996, June 28). Vidomosti Verkhovnoi Rady Ukrainy - Bulletin of Verkhovna Rada of Ukraine. Kyiv: Parlam. vyd-vo [in Ukrainian].

2. Zakon Ukrayiny «Pro osnovy" nacional'noyi bezpeky” Ukrayiny”» pryiniatyi 19 chervnya 2003 roku № 964-IV [The Law of Ukraine "On National Security of Ukraine" from 19 June 2003, № 964-IV]. (2003, September 26). Vidomosti Verkhovnoi Rady Ukrainy - Bulletin of Verkhovna Rada of Ukraine. Kyiv: Parlam. vyd-vo, 39 [in Ukrainian].

3. Zakon Ukrayiny” «Pro oxoronu navkoly’shn'ogo pry'rodnogo seredovy’shha» pryiniatyi 25 cherv. 1991 r. № 1264-XII. [The Law of Ukraine "On Environmental Protection" from 25 Jun. 1991, № 1264-XII. ] (1991). Vidomosti Verkhovnoi Rady Ukrainy - Bulletin of Verkhovna Rada of Ukraine. Kyiv: Parlam. vyd-vo, 41 [in Ukrainian].

4. Brauweiler, Hans-Christian, Vojtasová, Pavla, \& Hrebicek, Jiri (Hrsg.) (1998): Umweltmärkte Mittel- und Osteuropa Potentiale für kleine und mittelständische Unternehmen mit innovativen Angeboten, Deutsch-tschechischer Workshop, Sammelband zur 7. Internationalen Fachmesse Envibrno, Brno (Brünn, Tschechische Republik) [in German].

5. Gibbs, A., Elliott, T., Vergunst, T., Ballinger, A., Hogg, D., Gentil, E., Fischer, C., \& Bakas I. (2014): Development of a Modelling Tool on Waste Generation and Management. Headline Project Report. Final Report for the European Commission DG Environment under Framework Contract № ENV.C.2/FRA/2011/0020. Bristol: Eunomia Research \& Consulting Ltd. Retrieved from: http://www.cri.dk/sites/cri.dk/files/cases/eu_waste_model_-_headline_report_v1.0.pdf.

6. Hogg, D., Vergunst, T., Elliott, T., Elliott, L., \& Corbin, M. (2015). Support to the waste targets review. Analysis of new policy options. Bristol: Eunomia Research \& Consulting Ltd. Retrieved from http://ec.europa.eu/environment/waste/pdf/Analysis\%20of\%20New\%20Policy\%200ptions\%20Eunomia\%20report\%202015.pdf.

7. Klampfl-Pernold, H., \& Gelbmann, U. (2006): Quantensprünge in der Abfallwirtschaft - Entwicklung eines innovationsorientierten Phasenmodells der europäischen Abfallwirtschaft. Aachen: Shaker Verlag. [in German]

8. Kramer, Matthias, \& Brauweiler, Hans-Christian (Hrsg.) (1999). Internationales Umweltrecht - Ein Vergleich zwischen Deutschland, Polen und Tschechien, Gabler, Wiesbaden [in German]

9. Andreytsev, V.I. (1992). Garantii effektivnosti ekologicheskoy ekspertizyi: sotsialno-pravovyie problemyi [Guarantees of the effectiveness of environmental expertise: socio-legal problems]. K.: Znanie [in Russian]

10. Balyuk, G.I. (2007). Problemy' udoskonalennya yury'dy'chnoyi vidpovidal'nosti za ekologichni pravoporushennya v konteksti stalogo rozvy'tku Ukrayiny'. [Problems of improving legal liability for environmental violations in the context of sustainable development of Ukraine]. Visny'k Ky'yivs'kogo nacz.universy'tetu im. T. Shevchenka. - Bulletin of Kyiv National University. Shevchenko, 74 [in Ukrainian]. 
11. Bondar, L.O., \& Kurzova, V.V.(2008). Ekologichne pravo Ukrayiny' [Environmental Law Ukraine]. (2nd ed., Ext., And rev.). Xarkiv: Burun Kny’ga [in Ukrainian].

12. Get'man, A.P. (2009) Kody'fikaciya zakonodavstva pro dovkillya: teoriya ta metodologiya [Codification of the legislation on the environment: theory and methodology]. Ekologichny ’j visny`k - Ecological Bulletin, 3, 31-32 [in Ukrainian].

13. Derkachova, L.V. (2011). Zakonodache zakriplenya recy`klingu yak neobxidnoyi novaciyi u sferi povodzhennya $z$ vidxodamy' [Zakonodache clamped recycling as a necessary innovations in the field of waste management]. Extended abstract of candidate's thesis. Kyiv [in Ukrainian].

14. Savulyak, V.I., \& Berezyuk, O.V. (2006). Texnichne zabezpechennya zby'rannya, perevezennya ta pidgotovky do pererobky' tverdy 'x pobutovy'x vidxodiv [Technical support collection, transportation and preparation for solid waste]. Vinny'cya: UNIVERSUM-Vinny'cya [in Ukrainian].

15. Shemshuchenko, Yu. S. (2005). Natsionalnyie interesyi i Ekologicheskoe pravo [National Interests and Environmental Law]. Zhurnal rossiyskogo prava - Journal of Russian Law, 12, 92-96 [in Russian].

16. Manus Coffey, \& Adrian Coad. (2010). Collection of Municipal Solid Waste in Developing Countries. Kenya.

17. Johannessen, M.L. (1999).Guidance Note on Recuperation of Landfill Gas from Municipal Solid Waste Landfills. Urban Waste Management, 4, 34.

18. Shkola, V.Yu., Prokopenko, O.V., \& Domashenko, M.D. (2014). Perspektivyi innovatsionnogo razvitiya natsionalnoy ekonomiki na osnove vtorichnoy pererabotki othodov [Prospects for innovative development of the national economy on the basis of waste recycling]. Ustoychivoe razvitie predpriyatiya, regiona, obschestva: innovatsionnyie podhodyi $k$ obespecheniyu Sustainable development of an enterprise, region, society: innovative approaches to ensuring (pp. 217-228). Polsha: «Drukarnia i Studio Graficzne Omnidium» [in Russian].

19. Handbook on the Implementation of EC Environmental Legislation (2008). (n.d.). ec.europa.eu. Retrieved from: http://ec.europa.eu/environment/enlarg/handbook/i ntro.pdf.

20. Mishenin, Ye.V. (Eds.). (2013). Determinanty' social'no-ekonomichnogo rozvy'tku pidpry 'yemstv [Determinants of social and economic development of companies] (2nd ed.). Xarkiv: TOV «Disa Plyus». [in Ukrainian].

21. Illyashenko, S.M. (2002). Formuvannya ry’nku ekologichny'x innovaci]: ekonomichni osnovy` upravlinnya [Formation of environmental innovations market: the economic foundations of management]. Sumy`: VTD "Universy'tets`ka kny'ga» [in Ukrainian].

22. Parvy'na, T.G. (2008). Sut organizacijno-ekonomichnogo mexanizmu upravlinnya innovacijnoyu diyal'nistyu [The essence of organizational and economic mechanism innovation management]. Donecz'k: DonNTU. Retrieved from: http://masters.donntu.edu.ua/2008/fem/parvina/library/st1.htm [in Ukrainian].

23. Frolova, A. V. (2011). Formuvannya organizacijno-ekonomichnogo mexanizmu upravlinnya zabezpechennyam ekologichnoyi bezpeky derzhavy' [Formation of the organizational-economic mechanism of environmental security of the state]. Problemy sy'stemnogo pidxodu v ekonomici - Problems systematic approach to the economy, 4. Retrieved from: http://archive.nbuv.gov.ua/ejournals/pspe/2011_4/Frolova_411.htm [in Ukrainian].

24. Shkil’nyuk, O.M. (2008). Organizacijno-ekonomichny j mexanizm regulyuvannya innovacijnoyi diyal'nosti [Organizational and economic mechanisms of innovation]. Extended abstract of candidate's thesis. Ky'yiv: Naukovo-doslidny”j ekonomichny”j insty tut [in Ukrainian].

25. Review of Waste Policy and Legislation. (n.d.). ec.europa.eu. Retrieved from: http://ec.europa.eu/environment/waste/target_review.htm.

26. Zakon Ukrayiny "Pro vidxody»" [Law of Ukraine "On Waste"]. (n.d.). zakon3.rada.gov.ua. Retrieved from: www.rada.gov.ua [in Ukrainian].

27. Kazanchuk, I.D. (2010). Udoskonalennya administraty`vno-pravovogo regulyuvannya diyal'nosti organiv vy`konavchoyi vlady' shhodo oxorony` navkoly'shn'ogo pry'rodnogo seredovy'shha v umovax integraciyi Ukrayiny' u Yevropejs'ky’j soyuz [Improving the administrative and legal regulation of executive power on environmental protection in the integration of Ukraine into the European Union]. Visny 'k Xarkivs 'kogo nacional'nogo universy'tetu vnutrishnix sprav - Journal of Kharkov National University of Internal Affairs, 3, 131-138. Retrieved from: http://nbuv.gov.ua/UJRN/VKhnuvs_2010_3_19 [in Ukrainian].

28. Zarichans'ka, Ye.V. (2013). Organizacijno-ekonomichny”j mexanizm povodzhennya z promy’slovy'my` vidxodamy [Organizational-economic mechanism of industrial waste management]. Extended abstract of candidate's thesis. Donecz'k, Derzh. vy`shh. navch. zaklad «Donecz ky j nacional’ny”j texnichny j universy` tet» [in Ukrainian].

29. Malyej, O.V. (2013). Shlyaxy' udoskonalennya ekonomichnogo mexanizmu upravlinnya sferoyu povodzhennya $z$ tverdy'my' pobutovy 'my' vidxodamy' na regional'nomu rivni [Ways of improving economic mechanism of the treatment of solid waste at the regional level]. Komunal'ne gospodarstvo mist - Utilities city, 111, 41-47. Retrieved from: http://eprints.kname.edu.ua/35341/1/41-47\%20\%D0\%9C\%D0\%B0\%D0\%BB\%D1 \% 94\% D0\%B9\%20\%D0\%9E \%D0\%92.pdf [in Ukrainian].

30. Yachmeneva, V.M., \& Zaytsev, N.V. (2005). Ekonomicheskiy mehanizm obespecheniya ekologicheskoy bezopasnosti regiona kak ob'ekt upravleniya [Economic mechanism for ensuring environmental security in the region as an object of management]. Kultura narodov Prichernomorya. - Culture of the peoples of the Black Sea region, 74, Vol.1, 100-104 [in Russian].

31. Basiye, K.K. (2008). Extended producer responsibility for the management of waste from mobile phone. Thesis for the fulfillment of the Master of Science in Environmental Sciences: June 2008. Lund, Sweden. 
32. Skakun, O.F. (2011). Teoriya derzhavy` i prava [Theory of law]. Kharkiv [in Ukrainian].

33. Nekrasova, M. E. (2004). Dogovor kak teoretiko-pravovaya kategoriya [Treaty as a theoretical and legal category]. Extended abstract of candidate's thesis. Moskva [in Russian].

34. Tihomirov, Yu.A. (1990). Dogovor kak regulyator obschestvennyih otnosheniy [The contract as a regulator of public relations]. Pravovedenie. - Jurisprudence, 5, 27- 35 [in Russian].

35. Zakon Ukrayiny" "Pro zabezpechennya sanitarnogo j epidemichnogo blagopoluchchya naselennya» [The Law of Ukraine "On sanitary and epidemiological welfare"]. (n.d.). zakon3.rada.gov.ua. Retrieved from: http://zakon3.rada.gov.ua/laws/show/400412 [in Ukrainian].

36. Zakon Ukrayiny` «Pro Osnovni zasady` (strategiyu) derzhavnoyi ekologichnoyi polity 'ky` Ukrayiny` na period do 2020 roku» [The Law of Ukraine "On the Basic Principles (Strategy) of the State Environmental Policy of Ukraine till 2020"]. (n.d.). zakon3.rada.gov.ua. Retrieved from: http://zakon3.rada.gov.ua/laws/show/2818-17 [in Ukrainian].

37. Nacional'na strategiya povodzhennya $z$ tverdy 'my' pobutovy'my' vidxodamy' $v$ Ukrayini [National Strategy of Solid Waste Management in Ukraine]. Retrieved from: http://eco.kiev.ua/novyny/nac_strategija_povodjennja_z_vidkhodamy/? gclid=Cj0KEQjww7zHBRCToPSj_c_WjZIBEiQAj8il5Ab4Rx-XCel8OkxnEgOjpYoci-nuy87FhfNfsxpfRx8aApD58P8HAQ [in Ukrainian].

38. Kodeks pro administraty vni pravoporushennya [Code of Administrative Violations]. (n.d.). zakon3.rada.gov.ua. Retrieved from: http://zakon3.rada.gov.ual/laws/show/80731-10 [in Ukrainian].

39. Kry'minal'ny'j kodeks Ukrayiny' [Criminal code of Ukraine]. (n.d.). zakon3.rada.gov.ua. Retrieved from: http://zakon3.rada.gov.ua/laws/show/2341-14 [in Ukrainian].

X.-К. Браувэйлер, Doctor rerum politicarum, профресор, почесний професор, професор кафедри економіки та організації виробництва, управлінського обліку та внутрішнього аудиту, Університет прикладних наук (м. Цвікау, Німеччина);

B.Ю. Школа, канд. екон. наук, доцент, доцент кафедри економічної теорії, Сумський державний університет (м. Суми, Україна);

E.О. Маркова, канд. юрид. наук, доцент кафедри правових дисциплін, Сумський філіал Харківського університету внутрішніх справ (м. Суми, Україна)

Економіко-правовий механізм управління у сфері поводження з відходами в Україні

В статті проаналізовані існуючі проблеми системи управління відходами в Україні. Визначено сутність економікоправового механізму управління у сфрері поводження з відходами з позиції системного підходу. Досліджені методи управління відходами та на основі аналізу системи правових норм запропоновано напрями їх удосконалення

Ключові слова: відходи, управління відходами, сфера поводження з відходами, економіко-правовий механізм, вторинні ресурси.

Х.-К. Браувэйлер, Doctor rerum politicarum, профессор, почетный профессор, профрессор кафедры экономики и организации производства, управленческого учета и внутреннего аудита, Университет прикладных наук (г. Цвикау, Германия);

B.Ю. Школа, канд. экон. наук, доцент, доцент кафедры экономической теории, Сумский государственный университет (г. Сумы, Украина);

E.O. Маркова, канд. юрид. наук, доцент кафедры правовых дисциплин, Сумский филиал Харьковского университета внутренних дел (г. Сумы, Украина)

Экономико-правовой механизм управления в сфере обращения с отходами в Украине

В статье проанализированы существующие проблемы системы управления отходами в Украине. Рассмотрена сущность экономико-правового механизма управления в сфере обращения с отходами с позиции системного подхода. Исследованы методы управления отходами и на основе анализа системы правовых норм предложены направления их усовершенствования.

Ключевые слова: отходы, управление отходами, сфера обращения с отходами, экономико-правовой механизм, вторичные ресурсы.

Отримано 14.01.2017 p 